\title{
Method for estimating the in situ growth rate for a large pelagic diatom of Rhizosoleniacea
}

\author{
Akira Kuwata $^{1, *}$, Hideyuki Kanazawa ${ }^{2}$, Masayuki Takahashi ${ }^{3, *}$ \\ ${ }^{1}$ Institut de Ciències del Mar (CSIC), Passeig Joan de Borbó s/n, E-08039 Barcelona, Spain \\ ${ }^{2}$ Department of Comparative Literature and Comparative Culture, College of Arts and Sciences, University of Tokyo, \\ Komaba, Megro-ku, Tokyo 153, Japan \\ ${ }^{3}$ Department of Biology, College of Arts and Sciences, University of Tokyo, Komaba, Megro-ku, Tokyo 153, Japan
}

\begin{abstract}
A method for estimating the in situ growth rate from the nuclear position of the pelagic diatom Pseudosolenia calcar-avis is proposed. The algal cells were seen to exhibit characteristic positioning of the nucleus during each cell cycle. Nucleus movement in the first several hours after cell division was consistent in this algal population. The position of the nucleus can be regarded as the quantitative index of duration time after cell division. Applying this index to the method proposed by McDuff \& Chisholm (1982; Limnol Oceanogr 27:783-788) has been shown to give an estimation for the daily averaged specific growth rate of the P. calcar-avis population. This method could be useful for the estimation of the in situ growth rate of other Rhizosoleniacea species in the ocean without the need for bottle incubations.
\end{abstract}

KEY WORDS: In situ growth rate Large pelagıc diatom Rhizosoleniacea

\section{INTRODUCTION}

Large diatoms are generally ubiquitous and present in low numbers in oligotrophic regions of the world's oceans. Why these large species are able to persist in extremely oligotrophic environments and why they sometimes bloom in such regions remain unanswered questions in the field of phytoplankton ecology (Guillard \& Kilham 1977).

Recently, Goldman (1988) proposed that the role of these large phototrophs in oceanic primary production may be far more important than previously believed. Large diatoms, blooming episodically, may make a disproportionately high contribution to new production, a possibility that may go unnoticed with conventional sampling strategies.

To further understand the ecology of large diatoms in the pelagic ecosystem, estimation of the in situ growth rates of individual populations is necessary. However, there are few studies estimating the growth

\footnotetext{
-E-mail: akira@masagran.icm.csic.es

$\because$ Addressee for reprint requests
}

rate of such diatoms using unialgal culture experiments (Goldman et al. 1992) or data of carbon content and carbon fixation of natural cells (Villareal \& Carpenter 1994).

Several methods have been used to estimate speciesspecific growth rate of phytoplankton in the field. Some make estimations from carbon-specific growth obtained by the measurement of activities of individual algal cells using autoradiography (Knochel \& Kalff 1976. Descolas-Gros 1980) or micropipetting labeled single cells from bottle incubations into scintillation vials (Rivkin \& Seliger 1981) Others use in situ 'cage cultures' of phytoplankton to estimate population growth rate directly (Owens et al. 1977, Sakshaug \& Jensen 1978). However, all of these methods are relatively tedious and require incubations which cause additional problems that do not occur under natural conditions (Venrick et al. 1977. Carpenter \& Lively 1980).

There are, however, several methods to estimate the in situ specific growth rates without incubation by determination of the mitotic index, i.e. that fraction of cells at a particular stage of the cell cycle (Swift et al. 1976, Weiler \& Chisholm 1976, Carpenter \& Chang 1988, Vaulot 1992). Applying these methods, the aver- 
age growth rate can be calculated according to the equation proposed by McDuff \& Chisholm (1982). These methods require an accurate estimate of the duration of a given cell cycle event, which is generally obtained experimentally. Using any long-lasting cell cycle event which can be measured quantitatively is essential for the practical application of growth estima. tion, particularly for natural populations (Carpenter \& Chang 1988).

Rhizosoleniacea are included in the major group of pelagic large diatoms (Guillard \& Kilham 1977). This algal group displays a unique positioning pattern of the nucleus during each cell cycle. This feature suggests that the position of the nucleus in each individual cell can be used as a quantitative index of a cell cycle event for this algal group. In this study, we applied this index to estimate the in situ growth rate of Rhizosoleniacea in a culture experiment.

\section{MATERIALS AND METHODS}

Pseudosolenia calcar-avis (Schultze) Sundström was isolated at a station of the North Pacific central gyre $\left(6^{\circ} \mathrm{N}, 175^{\circ} \mathrm{E}\right)$ during a cruise of the RV 'Hakurei- Maru' $(\mathrm{NH}-91-2)$ in September 1991. The culture was maintained in modified MET-44 medium (Schöne \& Schöne 1982 , Villareal 1990 ) at $20^{\circ} \mathrm{C}$ under a $14: 10 \mathrm{~h}$ light:dark cycle (the light was provided by daylight-type fluorescent tubes at ca $50 \mu \mathrm{mol} \mathrm{m} \mathrm{m}^{-2} \mathrm{~s}^{-1}$ ).

Experiments were carried out in the modified MET44 medium under the same temperature and light conditions as mentioned above. To examine the positioning of the nucleus of Pseudosolenia calcar-avis during the cell cycle, several cells of this alga were inoculated in each of 24 holes of a multiwell culture dish (Corning Cell Wells 25820) and incubated for $24 \mathrm{~h}$. The position of the nucleus, $x$, and the whole cell length, $l$, of each cell of this population (see Fig. 1a) were determined every 2 h during incubation. In this study, $x$ was defined as a distance from the center of the nucleus to the near end of the valve. The length-dependent effect on the nuclear position was analyzed by nonparametric analysis of variance, i.e. Kruskal-Wallis test (Sokal $\&$ Rohlf 1995). The time taken for nucleus positioning in each cell was determined from tracing the nucleus position. To determine the specific growth rate of this alga, a batch culture experiment was conducted using Erlenmeyer flasks with light and culture conditions as mentioned above. The initial volume of the culture was $300 \mathrm{ml}$. Over a $2 \mathrm{wk}$ period, $10 \mathrm{ml}$ of sample was removed every day for cell counting Each sample was fixed with glutaraldehyde $(2.5 \%, v / v)$ and settled in chambers before counting with an inverted microscope (Utermöhl 1958).

\section{RESULTS}

\section{Positioning pattern of nucleus during the cell cycle}

The cell growth patterns of Pseudosolenia calcaravis during a cell cycle were examined throughout a $24 \mathrm{~h}$ period using a cultured population. Fig. 1 shows a typical cell growth pattern. This algal cell elongated from $420 \mu \mathrm{m}$ at the beginning of the experiment to a maximum of $550 \mu \mathrm{m}$ at Hour 12 and then divided into 2 daughter cells which were 200 and $350 \mu \mathrm{m}$ long, respectively (Fig, 1b). Each daughter cell began to elongate immediately after cell division. At the beginning of the experiment, the nucleus of the algal cell was located $70 \mu \mathrm{m}$ from the near end of the cell, and then was seen to move to the center of the cell during elongation (Fig. 1c). The nucleus was seen to divide $220 \mu \mathrm{m}$ from the near end of the cell prior to mother cell separation. It was then found to be located $30 \mu \mathrm{m}$ from the near end of each separated daughter cell. Each nucleus then moved to the center of each daughter cell, where the positions were almost the same up to $4 \mathrm{~h}$ after cell division. After this time, the positioning of the nuclei in the 2 daughter cells was seen to differ. Relative positions of nuclei in the cells were obtained by dividing nucleus position by the whole cell length. These relative positions were seen to differ after cell division occurred, since the cell lengths of the daughter cells were different (Fig. 1d)

These results indicated that Pseudosolenia calcaravis exhibited a characteristic positioning pattern of nuclei during a cell cycle (Fig. 1a). Nuclei of these algal cells were located near the dividing end of the cell immediately after division. Following this, the nucleus shifted towards the center of the cell as the cell lengthened. The nucleus was divided near the center of the mother cell prior to central mother divisions, and was seen to be located at the end of each separated daughter cell. Each nucleus exhibited a similar position in each daughter cell for several hours, despite the cell lengths of each daughter cell being different.

The distribution of nuclei positions within the culture population broadened after cell division (Fig. 2a). The mean position of the nucleus increased almost linearly from $30 \mu \mathrm{m}$ at $2 \mathrm{~h}$ to $73 \mu \mathrm{m}$ at $10 \mathrm{~h}$ after cell division. The average speed of the moving nucleus was obtained from the slope of Fig. 2a and found to be $5.4 \mu \mathrm{m} \mathrm{h}^{-1}$. The variance of nucleus position within this algal population also increased with time, as did the standard deviation of the distributions, which was found to increase from $5 \mu \mathrm{m}$ at $2 \mathrm{~h}$ to $22 \mu \mathrm{m}$ at $10 \mathrm{~h}$ after cell division. These results indicated that each cell of the population exhibited a similar positioning rate of the nucleus for the first few hours $(<4)$ after cell division 

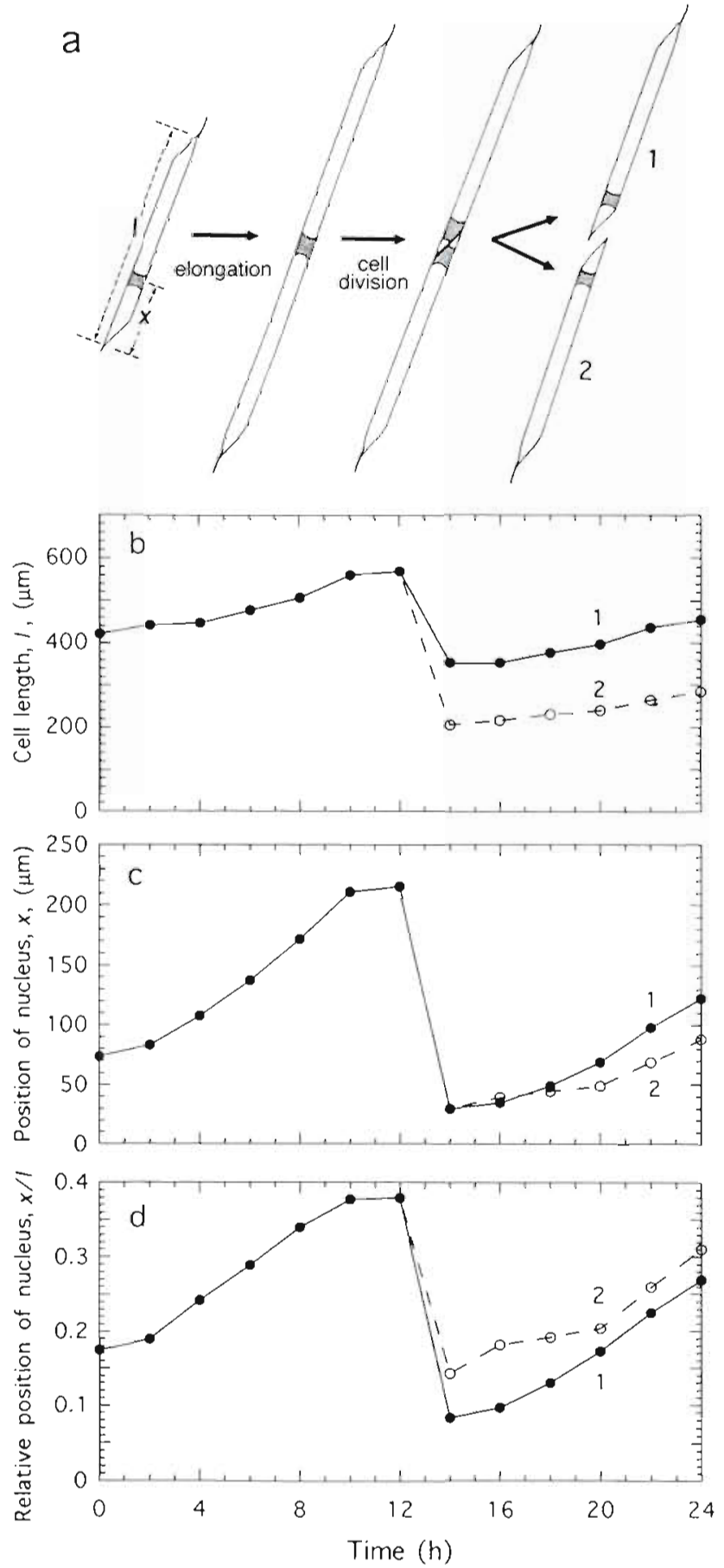

Fig. 1 Pseudosolenia calcar-avis. (a) Schematic diagram of positioning of nucleus (hatched area); and changes in (b) cell length, 1 ; (c) position of nucleus, $x$; and (d) relative position of nucleus of a individual cell, $x / 1$ during 1 cell cycle throughout $1 \mathrm{~d}$. Numbers 1 and 2 represent 2 daughter cells

Nucleus position was independent of cell size within $4 \mathrm{~h}$ after cell division (Kruskal-Wallis test, $\mathrm{p}=0.957$ ) (Table 1). Thus, the early position of the nucleus can be used as an index of a cell cycle event.

\section{Estimation of growth rate from positioning of nuclei}

To estimate the in situ average population growth rate of individual phytoplankton species, an accurate estimate of the duration of 1 cell cycle stage is needed. On estimating the in situ growth rate using this index, only information as to the position of the nucleus in each cell within the natural population was available. The duration of each individual cell with each cell nucleus position was determined in a cultured population of Pseudosolenia calcar-avis. As the position of the nucleus moved towards the center of the cell, the average duration increased almost linearly from $3.1 \mathrm{~h}$ at $30 \mu \mathrm{m}$ to $7.6 \mathrm{~h}$ at $60 \mu \mathrm{m}$ (Fig. 2b). The standard error of the average duration for each position at the early stage after cell division was around $0.5 \mathrm{~h}$. The minimum value was $0.42 \mathrm{~h}$ for $<40 \mu \mathrm{m}$ and the maximum was $0.64 \mathrm{~h}$ for $<60 \mu \mathrm{m}$.

Using these values of duration obtained from the culture experiment, the daily averaged growth rate of a cultured population of this alga can be estimated by modifying the method proposed by McDuff \& Chisholm (1982).
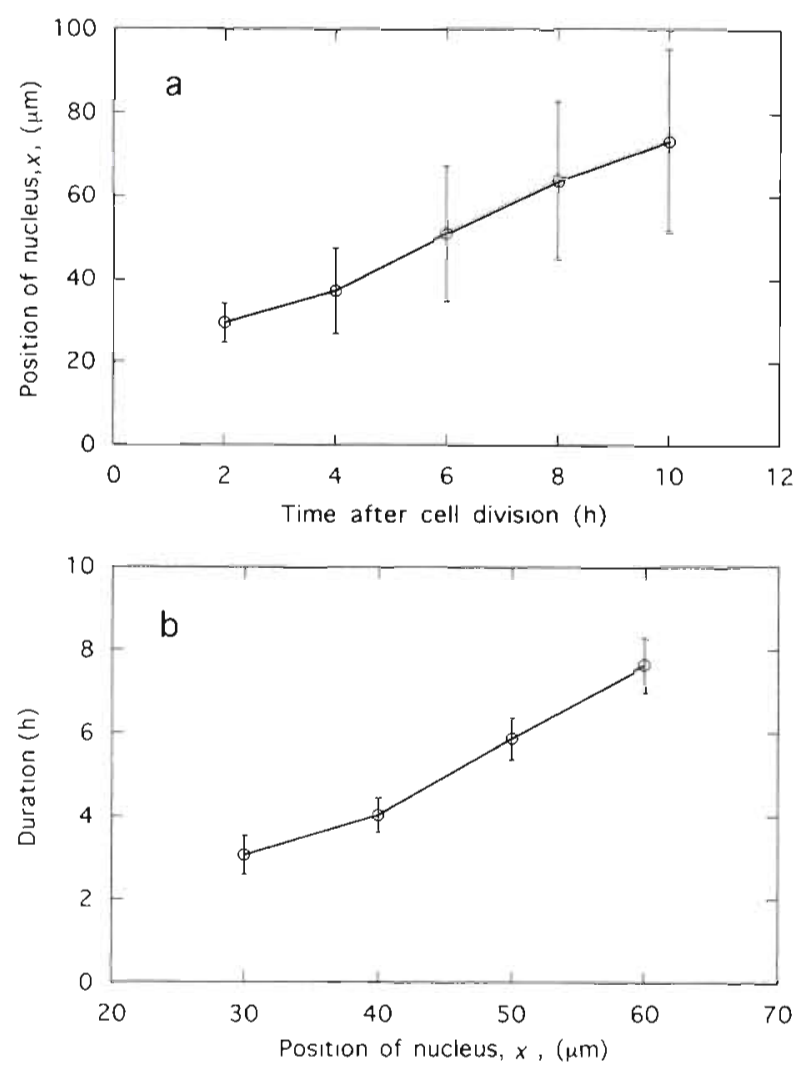

Fig. 2. Pseudosolenia calcar-avis. (a) Changes in the mean position of the nucleus, $x$, of a cultured population after cell division. Each bar represents standard deviation. (b) Changes in the mean duration time along with the moving of the nucleus, $x$, of a cultured population. Each bar represents standard error 
Table 1. Pseudosolenia calcar-avis. Size dependency of the position of the nucleus $4 \mathrm{~h}$ after cell division

\begin{tabular}{|ccccc|}
\hline \multicolumn{5}{c|}{ Cell length $(\mu \mathrm{m})$} \\
& $150-200$ & $200-250$ & $250-300$ & $>300$ \\
\hline Position of nucleus relative to end of cell $(\mu \mathrm{m})$ \\
Mean \pm SD & $35.1 \pm 3.7$ & $37.2 \pm 11.2$ & $37.6 \pm 11.5$ & $39.2 \pm 10.6$ \\
M.taximum & 39.2 & 63.7 & 49.0 & 53.9 \\
M. & 31.9 & 24.5 & 24.5 & 29.4 \\
No. of samples & 3 & 17 & 6 & 4 \\
\hline
\end{tabular}

The daily averaged growth rate of a cultured population of this alga was estimated using Eq. (6) of this method (Table 2). Estimated growth rates using present nuclei position analysis varied from 0.36 to $0.63 \mathrm{~d}^{-1}$, and the rate was seen to increase slightly with a change of nuclei position (Table 2). The average population growth rate of the same population determined by the direct cell count in the multiwell dish gave a value of $0.49 \mathrm{~d}^{-1}$ (Table 2), which was close to the value of $0.54 \mathrm{~d}^{-1}$ obtained by bottle culture

Of the algal population, whole cell numbers and numbers of cells already divided during time $t_{d}$ (the duration after cell division) which are distinguished by having a nucleus position less than a certain distance $x$ at time $t$ are $N(t)$ and $P(t)$, respectively. The total number of cells at time $t-t_{d}$ can be expressed as:

$$
N\left(t-t_{d}\right)=N(t)-P(t) / 2
$$

Assuming the logarithmic growth of the population from $t-t_{d}$ to $t$, total cell numbers of the population at time $t$ can be expressed with the following equation:

$$
N(t)=N\left(t-t_{d}\right) \mathrm{e}^{\bar{j}\left(t-t_{\alpha} t\right)}
$$

where $\bar{\mu}\left(t-t_{d} t\right)$ is the mean value of the growth rate over the interval from $t-t_{d}$ to $d$.

Thus,

$$
\begin{aligned}
\vec{\mu}\left(t-t_{d}, t\right) & =\frac{1}{t_{d}} \ln \frac{N(t)}{N\left(t-t_{d}\right)} \\
& =\frac{1}{t_{d}} \ln \frac{N(t)}{N(t)-P(t) / 2}
\end{aligned}
$$

The fraction of dividing cells in the population, $f_{\text {, at }}$ time $t-t_{d}$ can be expressed with the following equation:

$$
f\left(t-t_{d}\right)=\frac{P(t) / 2}{N(t)-P(t) / 2}
$$

Then,

$$
\vec{\mu}\left(t-t_{d}, t\right)=\frac{1}{t_{d}} \ln \left[1+f\left(t-t_{d}\right)\right]
$$

To apply Eq. (5) when $\bar{\mu}$ is not constant, we can calculate the daily averaged population growth rate from sequential observations of $f$ according to the same equation proposed by McDuff \& Chisholm (1982):

$$
\mu=\frac{1}{n t_{d}} \sum_{i=1}^{n} \ln \left(1+f_{i}\right)
$$

where $\mu$ is the daily averaged population growth rate $\left(\mathrm{d}^{-1}\right)_{i} f_{i}$ is the fraction of dividing cells in the $i$ th sample and $n$ is number of samples in a $24 \mathrm{~h}$ measuring cycle. experiment of the same strain under the same culture condition (Table 2). Considering the 4 different positions of a nucleus as indexes of cells immediately after cell division, a position of $<40 \mu \mathrm{m}$ gave the best estimate, $0.53 \mathrm{~d}^{-1}$, of the average rate of population growth of the present species.

\section{DISCUSSION}

A number of species of Rhizosoleniacea, including Pseudosolenia calcar-avis, are common large diatom species in the pelagic ocean (Sundström 1986). Pelagic large diatoms typically exist in very small population densities (Guillard \& Kilham 1977). This scarcity makes it difficult to determine their in situ growth rate by ordinary bottle incubations

McDuff \& Chisholm's (1982) method for the estimation of the in situ growth rate has the advantage of avoiding bottle incubation. This method requires a cell cycle event which exhibits a longer duration than a sampling interval; also, precise determination of this period results in the accurate estimation of the in situ growth rate. The mitosis stage, with paired nuclei in the cell, has been commonly used as a cell cycle event

Table 2. Pseudosolenia calcar-avis. Daily averaged population growth rates estimated from the nucleus position analysis and cell counts

\begin{tabular}{|lc|}
\hline $\begin{array}{l}\text { Mcthod of estimation } \\
\text { Nucleus position analysis }\end{array}$ & Growth rate $\left(\mathrm{d}^{-1}\right)$ \\
\hline $\begin{array}{l}\text { Position of nucleus relative to the end } \\
\text { of the coll: }\end{array}$ \\
$\quad<30 \mu \mathrm{m}$ & 0.36 \\
$<40 \mu \mathrm{m}$ & 0.53 \\
$<50 \mu \mathrm{m}$ & 0.61 \\
$<60 \mu \mathrm{m}$ & 0.63 \\
& \\
Direct cell count & 0.49 \\
Single cell culture in a multiwell dish, \\
the same population for nucleus analysis \\
Bottle culture
\end{tabular}


for such estimations (e.g Swift et al. 1976, Weiler \& Chisholm 1976, Braunwarth \& Sommer 1985). However, a disadvantage of this technique is that the interval of cell division can be relatively short, and the microscopic observation of cytokinesis can be subjective (Carpenter \& Chang 1988). In fact, it was hard to distinguish cells in the mitosis stage from those in the other stages of the cell cycle population even when observing nuclei of Pseudosolenia calcar-avis population stained with 4',6-diamidino-3-phenylindole (DAPI) under a fluoromicroscope. The duration of mitosis of this algal cell was also short, i.e. less than $2 \mathrm{~h}$.

This method has been modified in order to estimate the in situ growth rate of a planktonic algal population without the need for a culture experiment by determining the proportion of the subpopulation entering the $G 2$ and $M$ stages in the cell cycle which lasted a relatively long period (Carpenter \& Chang 1988, Chang \& Carpenter 1988). However, this method can only be applied when using the microfluorometry technique to determine cellular DNA contents.

In this study, it was revealed that Pseudosolenia calcar-avis exhibits a characteristic positioning of the nucleus during 1 cell cycle (Fig 1). It was also revealed that the intracellular movement of the nucleus for the first $4 \mathrm{~h}$ after cell division is consistent within the P. calcar-avis population (Fig 2a, Table 1). The position of the nucleus in this species can be used as a quantitative index of duration after cell division for McDuff \& Chisholm's (1982) method (Fig 2b). Estimations of specific growth rates using these indices were consistent with those obtained using the direct cell counting method, to within 30\% (Table 2). Using a duration corresponding to a nucleus movement of less than $40 \mu \mathrm{m}$ from the near end of the cell produced the most accurate estimation of the specific growth rate, i.e. within $10 \%$ of estimations using direct cell counting (Table 2).

To estimate the in situ growth rate using the method of McDuff \& Chisholm (1982), 1 cell cycle event of greater duration than the sampling interval is preferred (McDuff \& Chisholm 1982). Due to the very small population density of this algal population in pelagic water, large volumes of water are needed which may require long time periods for collection. The time taken for the nucleus to shift to less than $40 \mu \mathrm{m}$ from the near end of the cell is about $4 \mathrm{~h}$, which is long enough to enable adequate field sampling (Fig 2b).

In applying this method to obtain an estimation of the in situ growth rate, it should be noted that small changes in the duration, $t_{d}$, could make a large difference in the calculated growth rate using Eq. (6). The accuracy of this method depends on the maintenance of a constant duration of nucleus movement under varying conditions that might occur in natural water. For example, natural temperature variation can effect the duration time of this event, as observed by Weiler \& Epply (1979) in the duration of mitosis of dinoflagellates. Furthermore, the early positioning of the nucleus after cell division appears to be involved in the G1 phase, although correlations between nucleus position and cell cycle stages were unclear in this study. For example, it has been reported that a marine diatom Thalassiosira weissflogii was arrested in G1 phase under light and nutrient limitation (Olson et al. 1986. Vaulot et al. 1987). This phenomena might occur in Pseudosolenia calcar-avis and affect the duration of early nucleus movement. The duration of $P$. calcar-avis nucleus movement may also vary depending on conditions such as temperature, light and nutrients. However, this study was carried out under only one regime. at $20^{\circ} \mathrm{C}$ with a $14 \mathrm{~h} \mathrm{light} \mathrm{(ca} 50 \mu \mathrm{mol} \mathrm{m} \mathrm{m}^{-2} \mathrm{~s}^{-1}$ ) : $10 \mathrm{~h}$ dark cycle and sufficient nutrients. If an accurate estimation of the in situ growth rate is required, estimations of duration of nucleus movement under varying conditions might be necessary.

In conclusion, although this method using the duration of nucleus movement after cell division might have limited accuracy, it could be available for the estimation of the in situ growth rate of this algae in the oligotrophic ocean. This method is convenient for field study since it needs neither bottle incubation nor special equipment for determination of cellular DNA content.

Since the nucleus being surrounded by cytoplasm and between large vacuoles within a solenoid shaped cell is a common feature of Rhizosoleniacea cells, characteristic intracellular movement of the nucleus during each cell cycle as observed in Pseudosolenia calcar-avis (Fig. 1) can be expected to be a general feature of Rhizosoleniacea species. Therefore, this method could be applicable to other species of Rhizosoleniacea than $P$. calcar-avis, although culture experiments to determine the duration of moving nucleus after cell division of these species are necessary for accurate estimation. When the growth rate of a species of Rhizosoleniacea in the field is required and no unialgal culture is available, the data from $P$. calcar-avis could be useful for the estimation of the in situ growth rate of such other species, even though this would be an approximation

Recently, it was revealed that some Rhizosoleniacea species might play an important role in the oligotrophic pelagic ecosystem (Villareal et al. 1993). However, no estimation of the in situ growth rate of Rhizosoleniaced has yet been attempted. This method could be very useful for gaining an understanding of this potentially important algal group in the ecosystem of the oligotrophic ocean 
Acknowledgements. We are grateful to Dr Joji Ishizaka, Mr Hiroshi Kiyosawa and 4 anonymous referees for their useful and critical comments about the manuscript. We also thank the crew members of RV 'Hakurei Maru' of the Metal Mining Organization and of Kansai Environmental Engineering Corporation for their help during sampling of the isolated strains. We further thank Miss Joanne Wray for editing the manuscript. This study was carricd out as a part of the Northwest Pacific Carbon (ycle Study (NOPACCS), which was supported by the New Energy and Industry Developmental Organization (NEDO). A.K. was supported by the National Institute Postdoctoral Fellowship from the Research Development Corporation of Japan.

\section{LITERATURE CITED}

Braunwarth C, Sommer U (1985) Analysis of the in situ growth rates of Cryptophyceae by use of the mitotic index technique. Limnol Oceanogr 30:893-897

Carpenter EJ, Chang J (1988) Species-specific phytoplankton growth rates via diel DNA synthesis cycles. I. Concept of the method. Mar Ecol Prog Ser 43:105-111

Carpenter EJ, Lively JS (1980) Review of estimates of algal growth using carbon-14 techniques. In: Falkowski P (ed) Primary productivity in the sea. Plenum Press, New York. p $1.61-178$

Chang J, Carpenter EJ (1988) Species-specific phytoplankton growth rates via diel DNA synthesis cycles. II. DNA quantification and model verification in the dinoflagellate Het erocapsa triquetra. Mar Ecol Prog Ser 44:287-296

Descolas-Gros C (1980) Use of track autoradiography in oceanography; evaluation of phytoplankton species productivity. J Plankton Res 2:23-32

Goldman JC (1988) Spatial and temporal discontinuities of biological processes in pelagic surface waters. In Rothchild BJ (ed) Towards a theory on biological and physical processes in the world ocean. Kluwer Academic, Dordrecht, p 273-296

Goldman JC, Hansell DA, Dennett MR (1992) Chemical characterization of three large oceanic diatoms: potential impact on water column chemistry. Mar Ecol Prog Ser 88 : $257-270$

Guillard RRL, Kilham P (1977) The ecology of marine planktonic diatoms. In: Werner $\mathrm{D}$ (ed) The biology of diatoms. University of California Press, Berkeley, p 372-469

Knochel R, Kalff J (1976) The application of grain density autoradiography to quantitative determination of algal species production: a critique. Limnol Oceanogr 21 $583-590$

McDuff R, Chisholm SW (1982) The calculation of in situ growth rates of phytoplankton populations from fractions of cells undergoing mitosis: a clarification. Limnol Oceanogr 27:783-788

Olson RJ, Vaulot D, Chisholm SW (1986) Effect of environ- mental stresses on the cell cycle of two marine phytoplankton species. Plant Physiol 80:918-925

Owens OVH, Dresler P, Crawford CC. Tyler MA, Seliger HH (1977) Phytoplankton cages for the measurement of in situ growth rates of mixed natural population. Chesapeake Sci 18:325-333

Rivkin RB, Seliger HH (1981) Liquid scintillation counting for ${ }^{14} \mathrm{C}$ uptake of single algal cells isolated from natural samples. Limnol Oceanogr 26:780-785

Sakshaug E, Jensen A (1978) The use of cage cultures in studies of the biochemistry and ecology of marine phytoplankton. Oceanogr mar Biol A Rev 16:81-106

Schöne HK, Schöne A (1982) Met-44: a weakly enriched seawater medium for ecological studies on marine plankton algae, and some examples of its applications. Botanica mar 25:117-122

Sokal RR, Rohlf FJ (1995) Biometry: the principles and practice of statistics in biological research, 3rd edn WH Freeman \& Co, New York

Sundström BG (1986) The marine diatom genus Rhizosolenia - a new approach to the taxonomy. PhD dissertation, Lund University

Swift E, Stuart M, Meunier V (1976) The in situ growth rates of some deep-living oceanic dinoflagellates: Pyrocystis fusiformis and Pyrocystis noctiluca. Limnol Oceanogr 21 $418-426$

Utermöhl H (1958) Zur Vervollkommnung der quantitativen Phytoplankton-Methodik. Mitt int Verein theor angew Limnol 9:1-38

Vaulot D (1992) Estimation of phytoplankton division rates by the mitotic index method: the $f_{\max }$ approach revisited Limmol Oceanogr 37:644-649

Vaulot D, Olson RJ, Merkel S, Chisholm SW (1987) Cell-cycle response to nutrient starvation in two phytoplankton species, Thalassiosira weissflogii and Hymenomonas cartae. Mar Biol 95:625-630

Venrick EC, Beers JR, Heinbokel JF (1977) Possible consequences of containing microplankton for physiological rate measurements. J exp mar Biol Ecol 26:55-76

Villareal TA (1990) Laboratory culture and preliminary characterization of the nitrogen-fixing Rhizosolenia-Richelia symbiosis. PSZN 1: Mar Ecol 11:117-132

Villareal TA, Altabet MA, Culver-Rymsza K (1993) Nitrogen transport by vertically migrating diatom mats in the North Pacific Ocean. Nature 363:709-712

Villareal TA, Carpenter EJ (1994) Chemical composition and photosynthetic characteristics of Ethmodiscus rex (Bacillariophyceae): evidence for vertical migration. J Phycol 30: $1-8$

Weiler CS, Chisholm SW (1976) Phased cell division in natural populations of marine dinoflagellates from shipboard cultures. J exp mar Biol Ecol 25:239-247

Weiler CS, Eppley RW (1979) Temporal pattern of division in the dinoflagellate genus Ceratium and its application to the determination of growth rate. J exp mar Biol Ecol 39:1-24

Manuscript first received: July 25, 1994

Revised version accepted: July 17, 1995 